\title{
Interactive Book Reading to Accelerate Word Learning in Bilingual Children with Developmental Language Disorder: A Preliminary Intervention Approach
}

Veronica Fierro, Speech-Language Hearing: Sciences and Disorders, University of Kansas, Lawrence, KS

Holly L. Storkel, Speech-Language-Hearing: Sciences and Disorders, University of Kansas, Lawrence, KS

Financial Disclosure: Veronica Fierro is a doctoral candidate at the University of Kansas. Holly L. Storkel is professor and chair at the University of Kansas. The authors do not have any relevant financial interests to disclose.

Nonfinancial Disclosure: Veronica Fierro has previously published in the subject area. Holly L. Storkel has previously published in the subject area.

\begin{abstract}
This article will describe a bilingual preliminary treatment method currently being utilized in a clinical research study to teach vocabulary to bilingual (Spanish/English) preschool aged (four to six year-old) children with Developmental Language Disorder (DLD). The objective of this treatment method is to advance English vocabulary while supporting the native language abilities of English Learners (ELs). In this bilingual treatment method, Spanish and English are used within the session, which includes the reading of books in English and Spanish and the teaching of vocabulary in English and Spanish.
\end{abstract}


Providing treatment to bilingual children with Developmental Language Disorder (DLD) remains a challenge for many speech-language pathologists (SLPs). DLD is the preferred term for language problems that interfere with daily life, have a poor prognosis, and are not associated with a clear biomedical etiology (Bishop, Snowling, Thompson, Greenhalgh, \& the CATALISE2 consortium, 2017). In spite of the increasing body of evidence in support of bilingual interventions, SLPs — particularly monolingual SLPs — continue to remain unguided with regard to examples of the best, research-based, empirically-tested treatment methods available (Durán, Hartzheim, Lund, Simonsmeier, \& Kohlmeier, 2016). Theoretically, the obvious advantage of bilingual intervention is that it targets both languages. Nevertheless, beyond theoretical support for bilingual intervention, the availability of published evidence on language intervention for bilingual children is limited (Thordardottir, Cloutier, Ménard, Pelland-Blais, \& Rvachew, 2015). SLPs have seen an increase of ELs on their caseloads and, yet, only 10\% of SLPs working in preschool settings rate themselves as very qualified to work with children from dual language learning backgrounds (Durán et al., 2016). Many, if most, ELs with DLD receive intervention only in English. According to Ebert, Kohnert, Pham, Disher, \& Payesteh (2014), the prevalent use of "English-only" treatment can be attributed to at least three reasons, including the critical shortage of bilingual SLPs, the belief that English should be the sole focus of instruction, and the immediate educational relevance of building on the second language (L2). Nevertheless, an English-only approach does not consider the roles that both languages play in the vocabulary development of ELs (Mendez, Crais, Castro, \& Kainz, 2015). Just like monolingual children need one language to be successful in their communicative environments, bilingual children need two languages to be successful in theirs (Kohnert, 2008; Goldstein, 2006). Language intervention studies have shown clear, positive effects specific to the language(s) of intervention, 
which is why only bilingual intervention results in positive changes in both languages (KayRaining Bird, Trudeau, \& Sutton, 2016). According to Durán et al. (2016), development of a home language and development of the majority language are not mutually exclusive and can be supported simultaneously in intervention.

Interactive storybook reading has been shown to be an effective treatment strategy for ELs with and without DLD in increasing vocabulary knowledge in English and Spanish (Restrepo, Morgan, \& Thompson, 2013; Tsybina \& Eriks-Brophy, 2010; Collins, 2010; Silverman, 2007; Mendez et al., 2015; Lugo-Neris, Jackson, \& Goldstein, 2010; Ulanoff \& Pucci, 1999; Roberts, 2008; and Leacox \& Jackson, 2014). The teaching of vocabulary to ELs with DLD is important considering that difficulties with word learning is one of the deficits frequently observed in children with DLD (Alt \& Plante, 2006; Alt, Plante, \& Creusere, 2004; Dollaghan, 1987; Gathercole, 1993; Gray, 2003, 2004, 2005; Nash \& Donaldson, 2005; Rice, Buhr, \& Nemeth, 1990; Rice, Oetting, Marquis, Bode, \& Pae, 1994) and vocabulary knowledge is a strong predictor of reading success, particularly for ELs with and without DLD (Catts, Fey, Tomblin, \& Zhang, 2002; Scarborough, 1998; Restrepo et al., 2013). Interactive storybook reading is a treatment strategy that can be implemented by various people (e.g., parents, teachers, paraprofessionals) and not just SLPs, particularly considering the limited number of bilingual professionals in the field (Duran et al., 2016). The vocabulary learning studies that only used the second language (L2) (Collins, 2010; Silverman, 2007) to increase vocabulary knowledge in English reported that providing definitions in English of vocabulary words, even when those words were very sophisticated or not central to the plot was helpful to the English word learning of typical ELs. However, the studies that utilized a bilingual approach (Ulanoff \& Pucci, 1999; Lugo-Neris et al., 2010; Leacox \& Jackson, 2014; Mendez et al., 2015; Roberts, 2008; Restrepo 
et al., 2013; Tsybina \& Eriks-Brophy, 2010) demonstrated that incorporating the L1 into treatment was more effective than only using the L2 in the teaching of vocabulary in English and Spanish to ELs with and without DLD. Furthermore, they all demonstrated that including the L1 does not compromise L2 learning (Roberts, 2008).

\section{Ongoing Interactive Book Reading Treatment Study with Bilingual Children}

In an ongoing interactive book reading study, three bilingual treatment methods, including two blocking conditions (Blocking: English First; Blocking: Spanish First-where the languages are used separately in different sessions) and a bridging condition (i.e., where the languages are intermixed within the same session) are being utilized to increase vocabulary learning in English and Spanish in EL preschoolers. Whereas blocking treatment methods have been shown to be effective in increasing vocabulary knowledge in EL preschoolers with DLD, bridging methods have only been tested (and demonstrated to be effective) for typical ELs. Furthermore, these treatment methods have never been compared to each other. In the following section, the bridging condition will be described as a treatment method that is demonstrating itself to be helpful in increasing vocabulary knowledge in English and Spanish in EL preschool children with DLD.

\section{Bridging Treatment Method}

\section{Materials}

The treatment format for this preliminary intervention approach borrowed from the methods used in Storkel, Voelmle, Fierro, Flake, Fleming, and Romine (2017) and Restrepo et al.'s (2013) vocabulary learning studies. Treatment is provided in a one-on-one format with one child per session. A total of three books (English and Spanish versions) are used for each participant and each book (English and Spanish version) is read for four days. The treatment 
materials, shown in Table 1, include the Spanish and English versions of six books and 30 target English vocabulary words and their Spanish translation equivalents (30 Spanish vocabulary words). Half of the books (3) and half of the words (15 in English and 15 in Spanish) are treated and the other half are untreated. The books and vocabulary words include a narrative book used by Restrepo et al. (2013), and five narrative books on culturally relevant topics used by Mendez et al. (2015). The selection of vocabulary by Mendez et al. (2015) include Tier 1 words that the literature suggests many ELs do not have in their core L2 lexicon, as well as Tier 2, mediumhigh-frequency words. Restrepo et al. (2013) used vocabulary words that were at the Tier 2 level for bilingual preschool children with language impairments, as agreed upon by four researchers.

Table 1. Books and Target Vocabulary

\begin{tabular}{|c|c|c|}
\hline $\begin{array}{c}\text { Book Title } \\
\end{array}$ & English Vocabulary & Spanish Vocabulary \\
\hline $\begin{array}{l}\text { Growing Up With Tamales/Los } \\
\text { Tamales de Ana (Zepeda, 2008) }\end{array}$ & $\begin{array}{l}\text { cornhusk } \\
\text { smear } \\
\text { tongs } \\
\text { handlebars } \\
\text { apron }\end{array}$ & $\begin{array}{l}\text { hoja de maíz } \\
\text { untar } \\
\text { pinzas } \\
\text { manubrio } \\
\text { delantal }\end{array}$ \\
\hline $\begin{array}{l}\text { Floppy in the Dark/Floppy en la } \\
\text { Oscuridad (VanGenechten, 2002). }\end{array}$ & $\begin{array}{l}\text { cape } \\
\text { tremble } \\
\text { tent } \\
\text { melted } \\
\text { flashlight }\end{array}$ & $\begin{array}{l}\text { capa } \\
\text { temblar } \\
\text { tienda de campaña } \\
\text { derretir } \\
\text { linterna } \\
\end{array}$ \\
\hline $\begin{array}{l}\text { It's Bedtime, Cucuy/A la Cama, } \\
\text { Cucuy (Galindo, 2008) }\end{array}$ & $\begin{array}{l}\text { tugging } \\
\text { shout } \\
\text { brow } \\
\text { whispers } \\
\text { sheep }\end{array}$ & $\begin{array}{l}\text { jalando } \\
\text { grita } \\
\text { ceja } \\
\text { susurra } \\
\text { ovejas }\end{array}$ \\
\hline $\begin{array}{l}\text { The Little Red Hen/La Gallinita } \\
\text { Roja (Ottolenghi, 2002) }\end{array}$ & $\begin{array}{l}\text { shed } \\
\text { wheat } \\
\text { beak } \\
\text { wheelbarrow } \\
\text { oven }\end{array}$ & $\begin{array}{l}\text { cobertizo } \\
\text { trigo } \\
\text { pico } \\
\text { carretilla } \\
\text { horno }\end{array}$ \\
\hline $\begin{array}{l}\text { Sip, Slurp, Soup, Soup/Caldo, } \\
\text { Caldo, Caldo (Bertrand, 1997) }\end{array}$ & $\begin{array}{l}\text { stewpot } \\
\text { slicing } \\
\text { ladle } \\
\text { embraces } \\
\text { bowl }\end{array}$ & $\begin{array}{l}\text { olla } \\
\text { picar } \\
\text { cucharon } \\
\text { abraza } \\
\text { tazón }\end{array}$ \\
\hline $\begin{array}{l}\text { The Party for Papá Luis/La Fiesta } \\
\text { Para Papá Luis (Bertrand, 2010) }\end{array}$ & $\begin{array}{l}\text { counting } \\
\text { blending } \\
\text { cage } \\
\text { grinning } \\
\text { pole }\end{array}$ & $\begin{array}{l}\text { contando } \\
\text { mezclando } \\
\text { jaula } \\
\text { sonriendo } \\
\text { palo }\end{array}$ \\
\hline
\end{tabular}




\section{Sequence of Treatment}

In Days 1-4 (Week 1), Book 1 is read, in Days 5-8 (Week 2), Book 2 is read, and in Days 9-12 (Week 3), Book 3 is read. The sequence is then repeated with the same books in the same order in Days 13-24 (Weeks 4-6). Five target words in each language are taught per book (See Table 1 for the books and target vocabulary used in the ongoing study). Days 25 and 26 are review sessions, in which the target vocabulary words taught in the previous weeks (15 words in each language) are reviewed, one day in English and one day in Spanish.

\section{Language Use During Each Session}

In this bilingual treatment method, treatment is provided in English and Spanish during each session with the percentage of each language use alternating on each day, such that on days one and three of each week, approximately 75\% Spanish and 25\% English are used, and on days two and four of each week, approximately 75\% English and 25\% Spanish are used.

\section{Bridging Interactive Book Reading Illustration}

As shown in Table 2, on Days 1 and 3 of each week, the target vocabulary is in Spanish and the vocabulary is taught through the provision of two definitions (one in Spanish; one in English), three synonyms (two in Spanish; one in English), and three context sentences (two in Spanish; one in English). On Days 2 and 4 of each week, the target vocabulary is in English and the vocabulary is taught through the provision of two definitions (one in English; one in Spanish), three synonyms (two in English; one in Spanish), and three context sentences (two in English; one in Spanish). On Week 7, the vocabulary is reviewed through the provision of one definition, one synonym, and two context sentences. On Day 1 of Week 7, the vocabulary, definitions, synonyms, and context sentences are all in Spanish and on Day 2 of Week 7, only English is used. In this treatment method, the Spanish and English versions of each book are 
read on alternating days. On Day 1 of each week, the Spanish version of the book is read, followed by the English version on Day 2, Spanish version on Day 3, and English version on Day 4. (Refer to Table 2 for a sample of how the bridging condition is being utilized in the current study.)

Table 2. Sample of Bridging Condition (Weeks of Treatment)

\begin{tabular}{|c|c|c|}
\hline $\begin{array}{l}\text { Weeks } \\
1-6\end{array}$ & $\begin{array}{l}\text { Day } 1 \text { \& } 3 \text { (Spanish version of book; target } \\
\text { words in Spanish) }\end{array}$ & $\begin{array}{l}\text { Day } 2 \text { \& } 4 \text { (English version of book; target } \\
\text { words in English) }\end{array}$ \\
\hline & $\begin{array}{ll}\text { - } & \text { Storybook read all in Spanish } \\
\text { - } & \text { Target vocabulary all in Spanish } \\
\text { - } & \text { Definitions: } 1 \text { in Spanish, } 1 \text { in English } \\
\text { - } & \text { Synonyms: } 2 \text { in Spanish, } 1 \text { in English } \\
\text { - } & \text { Context sentences: } 2 \text { in Spanish, } 1 \text { in English }\end{array}$ & $\begin{array}{ll}\text { - } & \text { Storybook read all in English } \\
\text { - } & \text { Target vocabulary all in English } \\
\text { - } & \text { Definitions: } 1 \text { in English, } 1 \text { in Spanish } \\
\text { - } & \text { Synonyms: } 2 \text { in English, } 1 \text { in Spanish } \\
\text { - } & \text { Context sentences: } 2 \text { in English, } 1 \text { in Spanish }\end{array}$ \\
\hline Week 7 & $\begin{array}{l}\text { Review of previously taught vocabulary all } \\
\text { in Spanish: } 1 \text { definition, } 1 \text { synonym, and } 2 \\
\text { context sentences }\end{array}$ & $\begin{array}{l}\text { - Review of previously taught vocabulary all } \\
\text { in English: } 1 \text { definition, } 1 \text { synonym, and } 2 \\
\text { context sentences }\end{array}$ \\
\hline
\end{tabular}

\section{Individual Treatment Sessions}

One book is read during each treatment session and each session lasts approximately 1520 minutes. The teaching of the vocabulary is provided before, during, and after the reading of the storybooks. Prior to listening to the story (i.e., preview), the child hears a definition, a synonym, and a context sentence. During the story, the child hears the word within a context sentence from the story and a synonym. After the reading of the storybook (i.e., review), the child hears another context sentence, a synonym, and a definition. Tables 3 and 4 provide an example for "pico/beak". In Day 1 (Table 3), the storybook is read all in Spanish and the vocabulary is provided all in Spanish. Prior to the reading of the storybook, a picture depicting "pico" is shown and a definition and a synonym for "pico" are provided all in Spanish, followed by a context sentence in English. During the reading of the storybook, the child hears a context sentence from the book containing the word "pico". After the child hears the context sentence from the book, a synonym is provided in English. Following the reading of the storybook, a 
different picture of "pico" is presented, along with a context sentence and synonym in Spanish, and a definition of "pico" in English.

Table 3. Sample Lesson for "pico" (Book: La Gallinita Roja) in Bridging Condition, Day 1

$$
\text { Preview (Definition + Synonym + Context) }
$$

SAY: "Vamos a ver las palabras que vamos a escuchar en nuestra historia."

$\underline{\text { SHOW }} \quad \underline{\text { SAY Definition }} \quad \underline{\text { SAY Synonym }} \quad \underline{\text { SAY Context }}$

Picture

\begin{tabular}{lll|l}
\hline P 1. & $\begin{array}{l}\text { Pico significa la parte } \\
\text { dura de la cara de un } \\
\text { pájaro. }\end{array}$ & $\begin{array}{l}\text { Pico es como la } \\
\text { boca. }\end{array}$ & $\begin{array}{l}\text { The bird has a big pico } \\
\text { with many colors. }\end{array}$ \\
\hline
\end{tabular}

Book Reading (Text + Synonym + Definition)

SAY: "Vamos a leer nuestro libro y escuchar por esas palabras!"

\begin{tabular}{|c|c|c|c|}
\hline$\frac{\text { SHOW }}{\text { Book Pictur }}$ & READ Text & \multicolumn{2}{|l|}{ SAY Synonym } \\
\hline Page 14 & $\begin{array}{l}\text { "Lo cortó con su pico } \\
\text { afilado." }\end{array}$ & $\begin{array}{l}\text { Pico is like a } \\
\text { mouth. }\end{array}$ & \\
\hline \multicolumn{4}{|c|}{$\begin{array}{l}\text { Review (Naming + Context + Definition) } \\
\text { pensar sobre las palabras diferentes de nuestra historia." }\end{array}$} \\
\hline $\begin{array}{l}\text { SHOW } \\
\text { Context } \\
\text { Picture }\end{array}$ & $\underline{\text { SAY Context }}$ & SAY Synonym & SAY Definition \\
\hline R 1 & $\begin{array}{l}\text { El pájaro tiene un } \\
\text { gusano en su pico. }\end{array}$ & $\begin{array}{l}\text { Pico es como la } \\
\text { boca. }\end{array}$ & $\begin{array}{l}\text { Pico means the hard part of } \\
\text { a bird's face. }\end{array}$ \\
\hline
\end{tabular}

In Day 2 (Table 4), the storybook is read all in English and the vocabulary is provided all in English. Prior to the reading of the storybook, a picture depicting "beak" is shown and a definition and a synonym for "beak" are provided all in English, followed by a context sentence in Spanish. During the reading of the storybook, the child hears a context sentence from the book containing the word "beak". After the child hears the context sentence from the book, a synonym is provided in Spanish. Following the reading of the storybook, a different picture of "beak" is presented, along with a context sentence and synonym in English, and a definition of "beak" in Spanish. 
Table 4. Sample Lesson for "beak" (Book: The Little Red Hen) in Bridging Condition, Day 2

Preview (Definition + Synonym + Context)

SAY: "Let's look at some of the words we'll hear in our storybook."

$\underline{\text { SHOW }} \underline{\text { SAY Definition }} \underline{\text { SAY Synonym }} \underline{\text { SAY Context }}$

Definition

Picture

\begin{tabular}{|c|c|c|c|}
\hline P 1. & $\begin{array}{l}\text { Beak means the hard } \\
\text { part of a bird's face. }\end{array}$ & $\begin{array}{l}\text { Beak is like a } \\
\text { mouth. }\end{array}$ & $\begin{array}{l}\text { El pájaro tiene un beak } \\
\text { grande con muchos } \\
\text { colores. }\end{array}$ \\
\hline \multicolumn{4}{|c|}{$\begin{array}{l}\text { Book Reading (Text + Synonym + Definition) } \\
\text { SAY: "Let's read our storybook and listen for those words!" }\end{array}$} \\
\hline$\underline{\text { SHOW }}$ & READ Text & SAY Synonym & \\
\hline Page 14 & $\begin{array}{l}\text { "She cut it with her } \\
\text { sharp beak." }\end{array}$ & $\begin{array}{l}\text { Beak es como la } \\
\text { boca. }\end{array}$ & \\
\hline \multicolumn{4}{|c|}{$\begin{array}{l}\text { Review (Naming + Context + Definition) } \\
\text { nk about the different words from our storybook." }\end{array}$} \\
\hline $\begin{array}{l}\text { SHOW } \\
\text { Context } \\
\text { Picture }\end{array}$ & $\underline{\text { SAY Context }}$ & SAY Synonym & $\underline{\text { SAY Definition }}$ \\
\hline R 1. & $\begin{array}{l}\text { The bird has a worm in } \\
\text { his beak. }\end{array}$ & $\begin{array}{l}\text { Beak is like a } \\
\text { mouth. }\end{array}$ & $\begin{array}{l}\text { Beak significa la parte } \\
\text { dura de la cara de un } \\
\text { pájaro. }\end{array}$ \\
\hline
\end{tabular}

Following the treatment sessions, two review sessions are provided (one day in Spanish and one day in English), in which the target vocabulary words taught in the previous six weeks (15 words in each language) are reviewed. During the review days, all 15 experimental words are presented one at time, along with the two pictures that were used during the preview and review portion of the treatment sessions. Two context sentences, a synonym, and a definition are provided for each word as it is presented. Tables 5 and 6 provide an example of how the word "pico/beak" is reviewed. For the word "pico" (Table 5), the preview picture is presented and a definition and a context sentence are provided all in Spanish. The child is then immediately presented with the review picture and a synonym and a different context sentence are provided all in Spanish. 
Table 5. Sample of Review Session for "pico."

\begin{tabular}{llcl}
$\begin{array}{l}\text { (Preview picture) } \\
\text { SAY Definition }\end{array}$ & $\begin{array}{c}\text { (Preview picture) } \\
\text { SAY Context }\end{array}$ & $\begin{array}{c}\text { (Review picture) } \\
\text { SAY } \text { Synonym }\end{array}$ & $\begin{array}{c}\text { (Review picture) } \\
\text { SAY Context }\end{array}$ \\
\hline $\begin{array}{l}\text { Pico significa la parte } \\
\text { dura de la cara de un }\end{array}$ & $\begin{array}{l}\text { El pájaro tiene un } \\
\text { pico grande con } \\
\text { mújaro. }\end{array}$ & Pico es como la boca. & $\begin{array}{l}\text { El pájaro tiene un } \\
\text { gusano en su pico. }\end{array}$ \\
\hline
\end{tabular}

For the word "beak" (Table 6), the preview picture is presented and a definition and a context sentence are provided all in English. The child is then immediately presented with the review picture and a synonym and a different context sentence are provided all in English.

Table 6. Sample of Review Session for "beak."

\begin{tabular}{clll}
$\begin{array}{c}\text { (Preview picture) } \\
\text { SAY Definition }\end{array}$ & $\begin{array}{c}\text { (Preview picture) } \\
\text { SAY Context }\end{array}$ & $\begin{array}{c}\text { (Review picture) } \\
\text { SAY Synonym }\end{array}$ & $\begin{array}{c}\text { (Review picture) } \\
\text { SAY Context }\end{array}$ \\
$\begin{array}{l}\text { Beak means the hard } \\
\text { part of a bird's face. }\end{array}$ & $\begin{array}{l}\text { The bird has a big } \\
\text { beak } \text { with many } \\
\text { colors. }\end{array}$ & Beak is like a mouth. & $\begin{array}{l}\text { The bird has a worm } \\
\text { in his beak. }\end{array}$ \\
\hline
\end{tabular}

In the ongoing study, the participants are provided with 36 exposures to each word in each language (32 during treatment and an additional four during the review sessions) based on a recent study by Storkel et al., (2017) with kindergarteners with DLD, which demonstrated that the children made the most progress when 36 exposures were provided compared to 12,24 , and 48 exposures. In the case of the word "pico/beak", for example, Tables 3 and 4 will each have to be repeated a total of four times throughout the treatment for a total of 32 exposures. During the review sessions, the child will receive an additional four exposures per word in each language, totaling to 36 exposures. In this study, a script is strictly followed during the study to ensure the specified number of exposures are provided.

\section{Application of this Treatment Method to Practice}

Additional and more extensive research is needed on the bridging method and its use with ELs with DLD. Nevertheless, this exact treatment method (i.e., same books and words) can be 
applied in clinical practice or it can be modified with different books and words. Although 36 exposures are provided in this treatment method, an SLP can modify this intensity based on the needs of the child. SLPs can create materials and scripts for this treatment method using Tables 3-6 as a guide. They can begin by locating two pictures to represent each vocabulary word. These can be pictures from the internet, books, magazines, drawings, etc. One set of pictures can be used to preview the vocabulary before the book reading and the other set of pictures can be used to review the vocabulary after the story has been read. A PowerPoint presentation can be created with the pictures if a laptop computer or other electronic device will be used or the pictures can be printed on paper, which can then be laminated for durability. Definitions, synonyms, and two context sentences must be created for each vocabulary word. Clinicians may want to use dictionaries or internet resources for inspiration in constructing these and then rely on their clinical experience and skills to modify these examples to be appropriate for children with DLD. After a definition, synonym, and two context sentences have been created for each vocabulary word, the scripts can be made (see Tables 3 and 4). The scripts can be organized in a binder to match Days 1-4 of the book readings for each book. In the event that more than one person will be administering the treatment, this will allow the next person providing the treatment to pick up where the other one left off. The vocabulary words in the book should be highlighted in a way that will alert the interventionist to know when he/she needs to deviate from the story to provide a synonym for the targeted vocabulary word.

The treatment sessions can be administered to one child at a time or to small groups of two to three children. The children should be arranged in a way that will allow them to be able to see the pictures during the preview and review of the story, as well as the pictures in the book as the story is read. The interventionist should closely follow the script during the session to 
ensure that the children receive the appropriate amount of exposures to the vocabulary. The interventionist should begin the session by presenting each picture of the five vocabulary words and providing a definition, synonym, and context sentence. After previewing the vocabulary, the interventionist should then move on to the reading of the storybook. During the book reading, the interventionist should provide a synonym to each targeted vocabulary word as it is presented in the story. After the book reading, the second set of pictures of the vocabulary should be presented to the children and a context sentence, synonym, and definition should be given.

When the SLP decides to review the vocabulary that has been taught to the children during the book readings, a session in English and a session in Spanish can be held in which the two pictures for each vocabulary word are presented to the children and their corresponding definitions, synonyms, and context sentences can be read to them again, all in English during the English session and all in Spanish during the Spanish session.

It is recommended that the person administering this treatment is a fluent bilingual speaker. In the event that the SLP is not bilingual, another bilingual person (e.g., a paraprofessional, speech-language assistant, teacher, older sibling, and/or parent) can administer the treatment with guidance from the SLP. The SLP can provide a demonstration of the treatment method to the person who will be providing the intervention. In addition, the SLP should provide that person with the books and binder with the scripts. Each script should indicate which book it is intended for and whether the book is to be read in English or Spanish on that particular day. Another option would be to pre-record this treatment on an electronic device, such as an iPad or computer, and the child can follow along with guidance from an adult. This treatment method ensures that an EL child with DLD is receiving support in both his/her languages in the learning of vocabulary. Given that vocabulary is a significant predictor of 
reading comprehension in general and specifically in ELs, utilizing interventions that address vocabulary knowledge in ELs—-particularly ELs with DLD—is significantly important (Restrepo et al., 2013). 


\section{References}

Alt, M., \& Plante, E. (2006). Factors that influence lexical and semantic fast mapping of young children with specific language impairment. Journal of Speech, Language, and Hearing Research, 49(5), 941-954.

Alt, M., Plante, E., \& Creusere, M. (2004). Semantic Features in Fast-Mapping: Performance of Preschoolers With Specific Language Impairment Versus Preschoolers With Normal Language. Journal of Speech, Language, and Hearing Research, 47(2), 407-420.

Bishop, D. V. M., Snowling, M. J., Thompson, P. A., Greenhalgh, T., \& the CATALISE consortium (2017). Phase 2 of CATALISE: A multinational and multidisciplinary Delphi consensus study of problems with language development: Terminology. Journal of Child Psychology and Psychiatry, 1-13.

Catts, H. W., Fey, M. E., Tomblin, J. B., \& Zhang, X. (2002). A longitudinal investigation of reading outcomes in children with language impairments. Journal of Speech, Language, and Hearing Research, 45(6), 1142-1157.

Collins, M. F. (2010). ELL preschoolers' English vocabulary acquisition from storybook reading. Early Childhood Research Quarterly, 25, 84-97.

Dollaghan, C. A. (1987). Fast mapping in normal and language-impaired children. Journal of Speech \& Hearing Disorders, 52(3), 218-222

Durán, L. K., Hartzheim, D., Lund, E. M., Simonsmeier, V., \& Kohlmeier, T. L. (2016). Bilingual and home language interventions with young dual language learners: A Research synthesis. Language, Speech, and Hearing Services in Schools, 47, 347-371.

Ebert, K. D., Kohnert, K., Pham, G., Disher, J. R., \& Payesteh, B. (2014). Three treatments for bilingual children with primary language impairment: Examining cross-linguistic and cross-domain effects. Journal of Speech, Language, and Hearing Reearch, 57, 172-186.

Galindo, C. (2008). It's bedtime, Сucuy!/A la cama, Сucuy! Houston, TX: Arte Publico Press.

Gathercole, S. E. (1993). Word learning in language-impaired children. Child Language Teaching and Therapy, 9, 187-199.

Goldstein, B. A. (2006). Clinical implications of research on language development and disorders in bilingual children. Topics in Language Disorders, 4, 305-321.

Gonzales Bertrand, D. (1997). Sip, slurp, soup, soup/Caldo, caldo, caldo. Houston, TX: Piñata Books.

Gonzales Bertrand, D. (2010). The party for Papá Luis/La fiesta para Papá Luis [Bilingual ed.]. Houston, TX: Piñata Books.

Gray, S. (2003). Word-learning by preschoolers with Specific Language Impairment: What predicts success? Journal of Speech, Language, and Hearing Research, 46(1), 56-67. doi:10.1044/1092-4388(2003/005).

Gray, S. (2004). Word learning by preschoolers with specific language impairment: Predictors and poor learners. Journal of Speech, Language, and Hearing Research, 47(5), 1117 1132. doi:10.1044/1092-4388(2004/083).

Gray, S. (2005). Word learning by preschoolers with specific language impairment: Effect of phonological or semantic cues. Journal of Speech, Language, and Hearing Research, 48(6), 1452-1467. doi:10.1044/1092-4388(2005/101).

Kay-Raining Bird, E., Trudeau, N., \& Sutton, A. (2016). Pulling it all together: The road to lasting bilingualism for children with developmental disabilities. Journal of Communication Disorders, 63, 63-78. 
Kohnert, K. (2008). Language Disorders in Bilingual Children and Adults. San Diego, CA: Plural Publishing.

Leacox, L. \& Jackson, C. W. (2014). Spanish vocabulary-bridging technology-enhanced instruction for young English language learners' word learning. Journal of Early Childhood Literacy, 14, 175-197.

Lugo-Neris, M. J., Jackson, C. W., \& Goldstein, H. (2010). Facilitating vocabulary acquisition of young English language learners. Language, Speech, and Hearing Services in Schools, 41, 314-327.

Mendez, L. I., Crais, E. R., Castro, D. C., \& Kainz, K. (2015). A culturally and linguistically responsive vocabulary approach for young Latino dual language learners. Journal of Speech, Language, and Hearing Research, 58, 93-106.

Nash, M., \& Donaldson, M. (2005). Word Learning in Children with Vocabulary Deficits. Journal of Speech Language and Hearing Research, 48, 426-438.

Ottolenghi, C. (2002). The little red hen/La gallinita roja. Greensboro, NC: Carson-Dellosa Publishing.

Restrepo, M. A., Morgan, G. P., \& Thompson, M. S. (2013). The efficacy of a vocabulary intervention for dual-language learners with language impairment. Journal of Speech, Language, and Hearing Research, 56, 748-765.

Rice, M. L., Buhr, J. C., \& Nemeth, M. (1990). Fast mapping word-learning abilities of language-delayed preschoolers. Journal of Speech and Hearing Disorders, 55(1), 33-42.

Rice, M. L., Oetting, J. B., Marquis, J., Bode, J., \& Pae, S. (1994). Frequency of input effects on word comprehension of children with specific language impairment. Journal of Speech \& Hearing Research, 37(1), 106-121.

Roberts, T. A. (2008). Home storybook reading in primary or second language with preschool children: Evidence of equal effectiveness for second-language vocabulary acquisition. Reading Research Quarterly, 43, 103-130.

Scarborough, H. S. (1998). Early identification of children at risk for reading disabilities: phonological awareness and some other promising predictors. In B. K. Shapiro, P. J. Accardo, \& A. J. Capute (Eds.), Specific reading disability: A view of the spectrum (pp. 75-119). San Diego: Singular Publishing.

Silverman, R. (2007). A comparison of three methods of vocabulary instruction during readalouds in kindergarten. The Elementary School Journal, 108, 97-113.

Storkel, H. L., Voelmle, K., Fierro, V., Flake, K., Fleming, K. K., \& Romine, R. S. (2017). Interactive book reading to accelerate word learning by kindergarten children with Specific Language Impairment: Identifying an adequate intensity and variation in treatment response. Language, Speech, and Hearing Services in Schools, 48, 16-30.

Thordardottir, E., Cloutier, G., Ménard, S., Pelland-Blais, E., \& Rvachew, S. (2015). Monolingual or bilingual intervention for Primary Language Impairment? A Randomized Control Trial. Journal of Speech, Language, and Hearing Research, 58, 287-300.

Tsybina, I. \& Eriks-Brophy, A. (2010). Bilingual dialogic book-reading intervention for preschoolers with slow expressive vocabulary development. Journal of Communication Disorders, 43, 538-556.

Ulanoff, S. H. \& Pucci, S. L. (1999). Learning words from books: The effects of read aloud on second language vocabulary acquisition. Bilingual Research Journal, 23, 409-422.

Van Genechten, G. (2002). Floppy in the dark. London, England: Mantra Lingua.

Zepeda, G. (2008). Growing up with tamales/Los tamales de Ana. Houston, TX: Arte Publico 
Press. 